\title{
Association between Cytomegalovirus and Ulcerative Colitis in Diabetic Patients
}

\author{
Ahmed Abd El-Twab ${ }^{1, *}$ MD. and Ayman Abdel Aziz ${ }^{2}$ MD.
}

* Corresponding Author: Ahmed Abd El-Twab

AhmedAbdeltawwab.206@azhar.edu.eg

Received for publication August 06, 2021; Accepted November 19, 2021; Published online November 19, 2021.

Copyright The Authors published by Al-Azhar University, Faculty of Medicine, Cairo, Egypt. Users have the right to read, download, copy, distribute, print, search, or link to the full texts of articles under the following conditions: Creative Commons Attribution-Share Alike 4.0 International Public License (CC $B Y-S A$ 4.0).

doi: 10.21608/aimj.2021.81355.1506

${ }^{I}$ Microbiology Department, Faculty of Medicine, Al-Azhar University Cairo, Egypt.

${ }^{2}$ Theodore Bilharz Research Institute, Cairo, Egypt.

\begin{abstract}
Background: Ulcerative colitis (UC) is a chronic inflammatory colon disease that is becoming more prevalent around the world. The pathogenesis is influenced by microbial infections, genetic predisposition, epithelial barrier defects, dysregulated immune responses, and environmental factors. Microbial infections have been linked to UC in a variety of ways. One of the opportunistic viral infections linked to this disease is cytomegalovirus (CMV).

Aim of the work: to detect the role of CMV infection in diabetic patients with UC.

Material and methods: This study carried out on 185 patients (105 diabetics and 80 non-diabetics) attending and admitted in the Theodore Bilharz Research Institute at the Clinic and the Department of Gastroenterology from January, 2019 till January, 2021. At the end of the 1st year of coloscopic follow up, biopsies taken from all patients for detection of CMV associated colonic infection using polymerase chain reaction (PCR).

Results: CMV was found to be positive in $6.7 \%$ (7/105) of the diabetic patients with UC and $2.5 \%$ (2/80) of the non-diabetic patients with UC. Conclusion: A connection between UC and CMV has been detected, but further research is needed to determine the pathogenesis on a large scale.

Keywords: Cytomegalovirus; Ulcerative colitis; Diabetes.

Disclosure: The authors have no financial interest to declare in relation to the content of this article. The Article Processing Charge was paid for by the authors.

Authorship: All authors have a substantial contribution to the article.
\end{abstract}

\section{INTRODUCTION}

Ulcerative colitis (UC) is a chronic inflammatory bowel disease that causes ulcers and mucosal erosions in the colon. ${ }^{1}$ It is thought to be caused by a mix of genetic disorders, microbial infections, and environmental factors, including diet, but the exact cause is unknown. ${ }^{2}$ UC is characterized by inflammation of the colonic mucosa, which causes gastrointestinal symptoms such as diarrhea, hematochezia, and abdominal pain, and necessitates immunosuppressive therapy on a regular basis. ${ }^{2}$

Human CMV, is an opportunistic virus tangled in many inflammatory syndromes. ${ }^{3}$ Diagnosing CMV related colitis is difficult due to a lack of specific medical and endoscopic signs that distinguish CMV colitis from other types of colitis. ${ }^{4,5}$

CMV reactivation is disrupted in immunocompromised people, and is mediated by both CMV specific antibodies and CD8 positive Tcells in healthy people. ${ }^{6,7}$ As a result of the use of immunosuppressive drugs, especially corticosteroids, and chronic inflammation in the colonic mucosa, patients with immunocompromised conditions and those with medically refractory UC may be susceptible to CMV infection. ${ }^{6,7,8}$ Multiple methods used for accurate detection of CMV associated infection including tissue PCR. ${ }^{8,9}$

\section{PATIENTS AND METHODS}

Clinical description of the studied groups:

This study carried out on 185 patients, attending Theodore Bilharz Research Institute at the Clinic and the Department of Gastroenterology from January, 2019 till January, 2021. All of them diagnosed clinically, radiologically, laboratory and endoscopically with UC. The patients were divided into two groups; diabetic group included 105 cases, and non-diabetic group included 80 cases. Both groups were on the same regimen for treatment of UC including salicylates, corticosteroids with or without antibiotics. All of them were examined endoscopically every 6 months to detect any complications, flaring up or treatment failure. Failure of medical treatment was detected in 62 patients after 6 months. At the end of the $1^{\text {st }}$ year, coloscopic biopsies were taken from all patients for detection of CMV associated colonic infection using PCR. The endoscopic index of Blackstone and the ulcerative colitis endoscopic index of severity (UCEIS) were used to score the disease severity on admission. ${ }^{10}$

\section{DNA Extraction:}

The DNA was extracted as recommended by the manufacturer's instructions using the QIAGEN ${ }^{\circledR}$ Tissue kit (QIAGEN®, Span).

Tissue PCR for CMV DNA: 
According to the manufacturer's instructions CMV genome of samples was replicated using basic primers (Table 5). The PCR reaction was carried out as planned in terms of time and temperature. Denaturation was performed at $95^{\circ} \mathrm{C}$ for 5 minutes, followed by 35 cycles of $95^{\circ} \mathrm{C}$ for 50 seconds, $60^{\circ} \mathrm{C}$ for 45 seconds, $72^{\circ} \mathrm{C}$ for 40 seconds, and $72^{\circ} \mathrm{C}$ for 5 minutes. On a $2 \%$ agarose gel, the PCR product was divided into $5 \mu \mathrm{L} .{ }^{8,9}$

\section{Statistical Analysis:}

Statistics were done using IBM SPSS statistics for windows, version 26.0. ${ }^{11}$ The t-test and 2 test were used to examine the correlation between the frequency of CMV and the incidence of UC, as well as compare tissue samples from the control group. At the $5 \%$ level, statistical significance was acknowledged.

-X-mean, SD standard deviation: to measure the central tendency of data and the distribution of date around their mean.

-Student's t test: for testing statistical significant difference between means of two samples.

-Q-test: to identify statistical outliers in data.
Quantitative data were described as mean \pm standard deviation in parametric data and as median (IQR) in non-parametric data and were analyzed using independent t-test with Mann Whitney test.

-X2 test (Chi square test): used to test statistical significant relation between different variable or grades (qualitative data) or percentages.

- Z-test: used to test statistical significant difference between two percentages.

N.B:

-Significant result is considered if $\mathrm{p}<0.05$.

-Highly significant result is considered if $\mathrm{p}<0.01$.

\section{RESULTS}

The current study included 185 patients with UC, 65 male and 40 females. Two studied groups were included diabetic group comprising 105 patients and non-diabetic group comprising 80 patients. (Table 1)

There was a statistically significant increase in smokers in the non-diabetic group. (Fig. 1)

\begin{tabular}{|c|c|c|c|c|c|c|c|}
\hline & & \multicolumn{2}{|c|}{$\begin{array}{c}\text { Diabetic group } \\
(\mathbf{1 0 5})\end{array}$} & \multicolumn{2}{|c|}{$\begin{array}{c}\text { Non-diabetic group } \\
(\mathbf{8 0})\end{array}$} & \multicolumn{2}{|c|}{$\begin{array}{l}\text { Chi square test/ } \\
\text { Independent } t \text { test }\end{array}$} \\
\hline & & No & $\%$ & No & $\%$ & $X^{2} / t^{*}$ & P value \\
\hline \multirow[t]{2}{*}{ Sex } & Female & 40 & $38.1 \%$ & 32 & $40.0 \%$ & \multirow[t]{2}{*}{0.069} & \multirow[t]{2}{*}{0.792} \\
\hline & Male & 65 & $61.9 \%$ & 48 & $60.0 \%$ & & \\
\hline \multirow[t]{2}{*}{ Age } & Mean \pm SD & \multicolumn{2}{|c|}{$44.25 \pm 2.15$} & \multicolumn{2}{|c|}{$44.12 \pm 3.15$} & \multirow[t]{2}{*}{0.33} & \multirow[t]{2}{*}{0.739} \\
\hline & Range & & & & & & \\
\hline \multirow[t]{2}{*}{ Smokers } & Yes & 38 & $36.2 \%$ & 58 & $72.5 \%$ & \multirow[t]{2}{*}{23.979} & \multirow[t]{2}{*}{0.001} \\
\hline & No & 67 & $63.8 \%$ & 22 & $27.5 \%$ & & \\
\hline \multirow{6}{*}{$\begin{array}{c}\text { Associated } \\
\text { medical } \\
\text { problems }\end{array}$} & Hypertensive & 18 & $17.1 \%$ & 6 & $7.5 \%$ & \multirow[t]{6}{*}{6.873} & \multirow[t]{6}{*}{0.230} \\
\hline & IHD & 5 & $4.8 \%$ & 3 & $3.8 \%$ & & \\
\hline & Hyperthyroidism & 1 & $1.0 \%$ & 0 & $0.0 \%$ & & \\
\hline & Rheumatoid arthritis & 8 & $7.6 \%$ & 0 & $0.0 \%$ & & \\
\hline & Cancer breast & 1 & $1.0 \%$ & 2 & $2.5 \%$ & & \\
\hline & Cancer prostate & 1 & $1.0 \%$ & 0 & $0.0 \%$ & & \\
\hline
\end{tabular}

Table 1: General records of the studied groups.

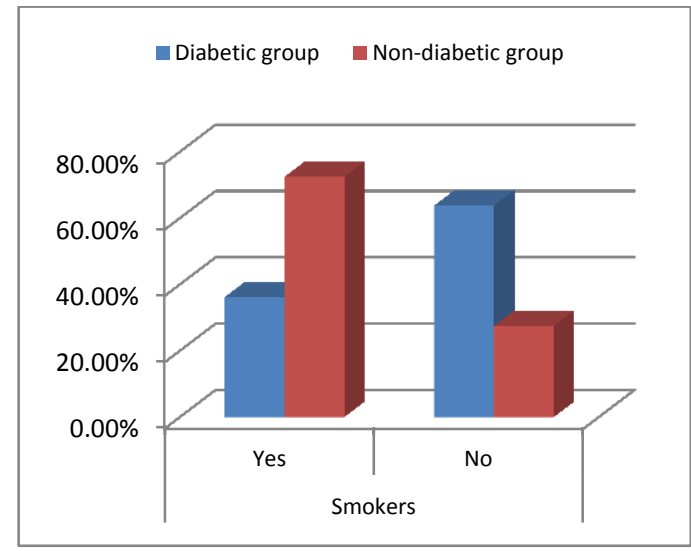

Fig. 1: Percentage of the smokers in the studied groups.

Sixty six patients $(62.9 \%)$ had bleeding pre rectum, 78 patients $(74.3 \%)$ had loss of weight, 42 patients (40\%) had pallor /anemia and 63 patients $(60 \%)$ had abdominal pain in diabetic group. (Table 2)

There was a statistically significant increase in

bleeding per-rectum, loss of weight, pallor /anemia and abdominal pain. (Fig. 2)

\begin{tabular}{|c|c|c|c|c|c|c|}
\hline & \multicolumn{2}{|c|}{$\begin{array}{c}\text { Diabetic } \\
\text { group } \\
(105)\end{array}$} & \multicolumn{2}{|c|}{$\begin{array}{c}\text { Non- } \\
\text { diabetic } \\
\text { group } \\
(80)\end{array}$} & \multicolumn{2}{|c|}{$\begin{array}{c}\text { Chi square } \\
\text { test }\end{array}$} \\
\hline & No & $\%$ & No & $\%$ & $\mathrm{X}^{2}$ & $\begin{array}{c}\mathbf{P} \\
\text { value }\end{array}$ \\
\hline $\begin{array}{l}\text { Bleeding } \\
\text { per-rectum }\end{array}$ & 66 & $62.9 \%$ & 13 & $16.3 \%$ & 40.311 & 0.001 \\
\hline $\begin{array}{l}\text { Loss of } \\
\text { weight }\end{array}$ & 78 & $74.3 \%$ & 11 & $13.8 \%$ & 66.652 & 0.001 \\
\hline $\begin{array}{c}\text { Pallor } \\
\text { /Anemia }\end{array}$ & 42 & $40.0 \%$ & 12 & $15.0 \%$ & 13.730 & 0.001 \\
\hline $\begin{array}{c}\text { Blood } \\
\text { transfusion }\end{array}$ & 11 & $10.5 \%$ & 4 & $5.0 \%$ & 1.828 & 0.176 \\
\hline $\begin{array}{l}\text { Chronic } \\
\text { diarrhea }\end{array}$ & 82 & $78.1 \%$ & 55 & $68.8 \%$ & 2.061 & 0.150 \\
\hline $\begin{array}{c}\text { Abdominal } \\
\text { pain }\end{array}$ & 63 & $60.0 \%$ & 36 & $45.0 \%$ & 4.107 & 0.042 \\
\hline
\end{tabular}




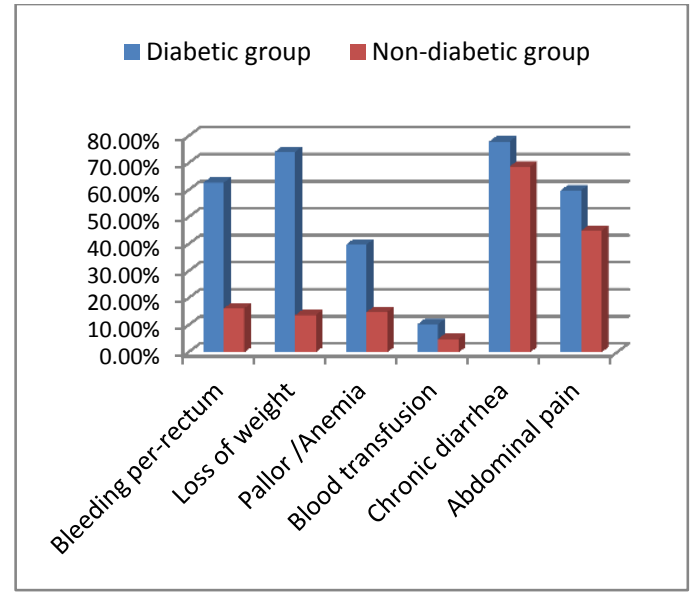

Coloscopic results and endoscopic score of the studied groups:

According to earlier accounts, we looked for longitudinal ulcers, large mucosal faults, and punched-out ulcers. 12 These were thought to be distinct characteristics of CMV infection. Endoscopic ulcers that did not fit these categories were defined as irregular ulcers. (Table 3,4) (Fig. 3)

Fig. 2: Percentage of different clinical presentations among the studied groups.

\begin{tabular}{|c|c|c|}
\hline $\begin{array}{c}\text { Descriptor (score of most severe } \\
\text { lesions) }\end{array}$ & Likert scale anchor points & Definition \\
\hline \multicolumn{3}{|l|}{ I-Vascular pattern } \\
\hline & Normal (0) & $\begin{array}{l}\text { Normal vascular patterns with } \\
\text { arborization of capillaries clearly } \\
\text { defined or with blurring or patchy loss } \\
\text { of capillary margins }\end{array}$ \\
\hline & Patchy obliteration (1) & Patchy obliteration of vascular pattern \\
\hline & Obliterated (2) & $\begin{array}{l}\text { Complete obliteration of vascular } \\
\text { pattern }\end{array}$ \\
\hline \multicolumn{3}{|l|}{ II-Bleeding } \\
\hline & None $(0)$ & No visible blood \\
\hline & Mucosal (1) & $\begin{array}{l}\text { Some spots or streaks of coagulated } \\
\text { blood on the surface of the mucosa } \\
\text { ahead of the scope that can be washed } \\
\text { away }\end{array}$ \\
\hline & Luminal mild (2) & Some free liquid blood in the lumen \\
\hline & Luminal moderate or severe (3) & $\begin{array}{l}\text { Frank blood in the lumen ahead of the } \\
\text { endoscope or visibly oozing from the } \\
\text { mucosa after washing intraluminal } \\
\text { blood, or visibly oozing from a } \\
\text { haemorrhagic mucosa }\end{array}$ \\
\hline \multicolumn{3}{|l|}{ III-Erosions and ulcers } \\
\hline & None $(0)$ & $\begin{array}{l}\text { Normal mucosa, no visible erosions or } \\
\text { ulcers }\end{array}$ \\
\hline & Erosions (1) & $\begin{array}{l}\text { Tiny }(5 \mathrm{~mm}) \text { defects in the mucosa of } \\
\text { a white or yellow colour with a flat } \\
\text { edge }\end{array}$ \\
\hline & Superficial ulcer (2) & $\begin{array}{l}\text { Larger }(>5 \mathrm{~mm}) \text { defects in the mucosa, } \\
\text { which are discrete fibrin- covered } \\
\text { ulcers when compared with erosions } \\
\text { but remain superficial }\end{array}$ \\
\hline & Deep ulcer (3) & $\begin{array}{l}\text { Deeper excavated defects in the } \\
\text { mucosa with slightly raised edge }\end{array}$ \\
\hline
\end{tabular}

Table 3: Ulcerative colitis endoscopic index of severity (UCEIS) scores and definitions.

Twenty four patients $(22.9 \%)$ had Lt .sided colitis and 81 patients $(77.1 \%)$ had pancolitis. Forty eight patients $(45.7 \%)$ their endoscopic score 8,57 patients $(54.3 \%)$ their endoscopic score between 6- 7 in diabetic group.

There were statistically significant increase pancolitis and Score 6-7 for pancolitis in diabetic group. (Table 4) 


\begin{tabular}{|c|c|c|c|c|c|c|c|}
\hline & \multicolumn{2}{|c|}{$\begin{array}{c}\text { Diabetic } \\
\text { group } \\
(105)\end{array}$} & \multicolumn{2}{|c|}{$\begin{array}{c}\text { Non- } \\
\text { diabetic } \\
\text { group } \\
(\mathbf{8 0})\end{array}$} & \multicolumn{2}{|c|}{$\begin{array}{c}\text { Chi square } \\
\text { test }\end{array}$} \\
\hline & & $\begin{array}{l}\mathbf{N} \\
\mathbf{0}\end{array}$ & $\%$ & $\begin{array}{l}\mathbf{N} \\
\mathbf{0}\end{array}$ & $\%$ & $\mathbf{X}^{2}$ & $\begin{array}{c}\text { P } \\
\text { val } \\
\text { ue }\end{array}$ \\
\hline \multirow[t]{2}{*}{ Colitis } & $\begin{array}{c}\mathrm{Lt} \\
\text { sidede } \\
\mathrm{d} \\
\text { colitis }\end{array}$ & $\begin{array}{l}2 \\
4\end{array}$ & $\begin{array}{c}22.9 \\
\%\end{array}$ & 9 & $\begin{array}{c}11.3 \\
\%\end{array}$ & \multirow[t]{2}{*}{$\begin{array}{c}4.17 \\
4\end{array}$} & \multirow[t]{2}{*}{$\begin{array}{c}0.0 \\
41\end{array}$} \\
\hline & $\begin{array}{c}\text { Panco } \\
\text { litis }\end{array}$ & $\begin{array}{l}8 \\
1\end{array}$ & $\begin{array}{c}77.1 \\
\%\end{array}$ & $\begin{array}{l}7 \\
1\end{array}$ & $\begin{array}{c}88.8 \\
\%\end{array}$ & & \\
\hline \multirow{3}{*}{$\begin{array}{c}\text { Endosc } \\
\text { opic } \\
\text { score }\end{array}$} & $\begin{array}{l}\text { Score } \\
8 \text { for } \\
\text { pancol } \\
\text { itis }\end{array}$ & $\begin{array}{l}4 \\
8\end{array}$ & $\begin{array}{c}45.7 \\
\%\end{array}$ & $\begin{array}{l}2 \\
8\end{array}$ & $\begin{array}{c}35.0 \\
\%\end{array}$ & \multirow{3}{*}{$\begin{array}{l}102 . \\
521\end{array}$} & \multirow{3}{*}{$\begin{array}{l}0.0 \\
01\end{array}$} \\
\hline & $\begin{array}{c}\text { Score } \\
6-7 \\
\text { for } \\
\text { pancol } \\
\text { itis }\end{array}$ & $\begin{array}{l}5 \\
7\end{array}$ & $\begin{array}{c}54.3 \\
\%\end{array}$ & 0 & $\begin{array}{c}0.0 \\
\%\end{array}$ & & \\
\hline & $\begin{array}{c}\text { Score } \\
5-6 \\
\text { for } \\
\text { pancol } \\
\text { itis }\end{array}$ & 0 & $\begin{array}{l}0.0 \\
\%\end{array}$ & $\begin{array}{l}4 \\
3\end{array}$ & $\begin{array}{c}53.8 \\
\%\end{array}$ & & \\
\hline
\end{tabular}

Table 4: Coloscopic findings in studied groups.
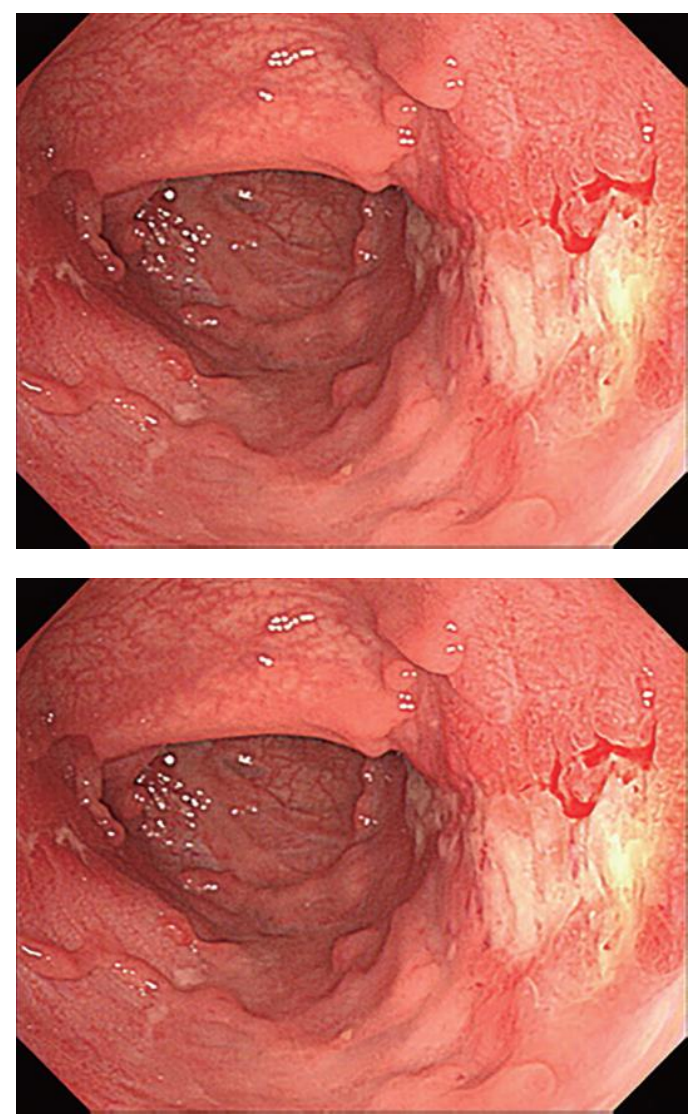

Fig.3:Endoscopic findings in patients with cytomegalovirus colitis.

Seven patients $(6.7 \%)$ were had positive PCR so there were no statistically significant deference between PCR among studied groups.

\begin{tabular}{ccccccc}
\hline & \multicolumn{2}{c}{$\begin{array}{c}\text { Diabetic group } \\
(\mathbf{1 0 5})\end{array}$} & $\begin{array}{c}\text { Non-diabetic group } \\
(\mathbf{8 0 )}\end{array}$ & \multicolumn{2}{c}{ Chi square test } \\
\cline { 2 - 7 } & No & $\%$ & No & $\%$ & X2 & P value \\
$\begin{array}{r}\text { PCR } \\
+ \text { Ve }\end{array}$ & 7 & $6.7 \%$ & 2 & $2.5 \%$ & & \\
\hline $\begin{array}{c}\text { PCR }- \\
\text { Ve }\end{array}$ & 98 & $93.3 \%$ & 78 & $97.5 \%$ & & \\
\hline
\end{tabular}

Table 5: PCR results of the studied groups.

A 106-bp band that reflects the amplification of the human $\beta$-globulin gene was found in all coloscopic tissue samples. (Fig. 4)

PCR analysis with CMV specific primers was performed due to the consistency and reliability of the DNA extracted; 167 bp bands representing replication were observed. (Fig. 5)

\begin{tabular}{|c|c|c|}
\hline Primer & Sequence & $\begin{array}{l}\text { Size, } \\
\text { bp }\end{array}$ \\
\hline B-globulin & & 106 \\
\hline $\mathrm{F}$ & 5' TCCAACATCAACATCTTGGT 3' & \\
\hline $\mathrm{R}$ & $\begin{array}{l}5, \text { TCCCCCAAATTCTAAGCAGA } \\
3^{\prime},\end{array}$ & \\
\hline CMV & & 167 \\
\hline $\mathrm{F}$ & $\begin{array}{c}\text { 5' GTCACCAAGGCCACGACGTT } \\
\text { 3, }\end{array}$ & \\
\hline $\mathrm{R}$ & 5' TCTGCCAGGACATCTTTCTC 3 , & \\
\hline
\end{tabular}

Table 6: Base pair (bp) length and sequences of primers.

Using primers mentioned in the methods, DNA extracted from tissue samples was amplified for the $\beta$-globulin gene. Amplification produced a 106bp band. Considering (P) is the positive control, DNA from fresh human tissue $(\mathrm{N})$ is the negative control and PCR master mix without DNA was used. Clinical samples, lanes 3- 11. Molecular weight for DNA marker, is (M). (Fig. 4)

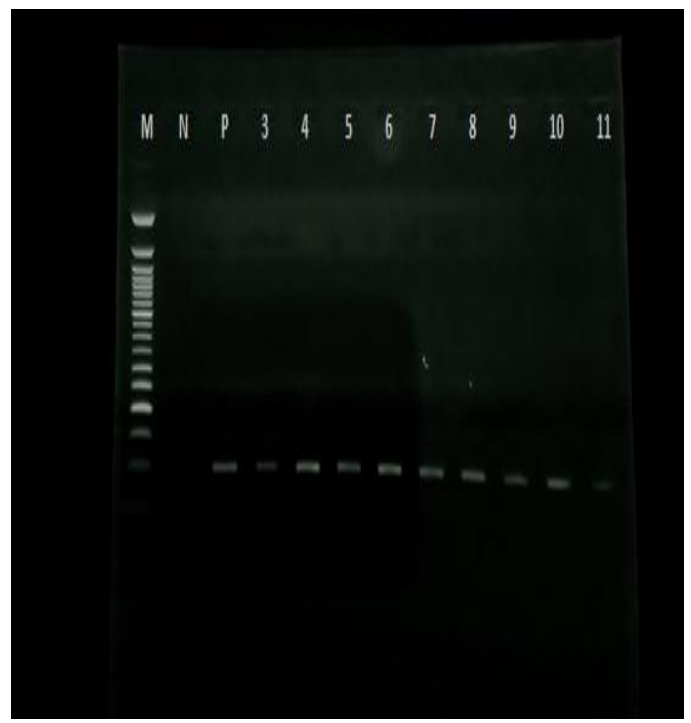

Fig. 4: $\beta$-globulin PCR analysis. 
DNA extracted from tissues was amplified with the aid of special primers. After amplification, the fragment formed a 167-bp band. Samples inoculated in lanes 3-11; DNA molecular weight marker (M); negative control $(\mathrm{N})$; positive control $(\mathrm{P})$ also included. (Fig. 5)

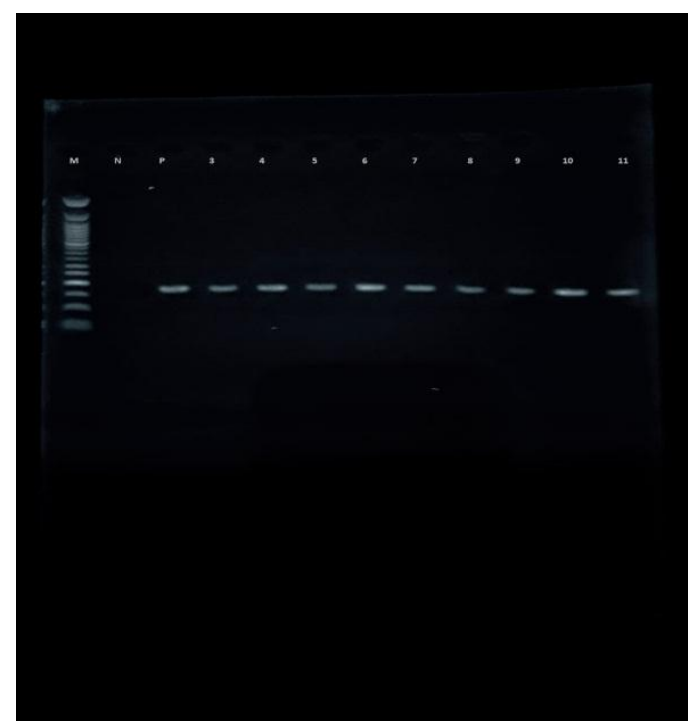

Fig. 5: PCR for detection of CMV from coloscopic tissue samples.

\section{DISCUSSION}

The existing research used colonic CMV DNA identification to detect the role of CMV in diabetic patients with UC. CMV is an opportunistic viral infection characterized by latency and recurrence. In a remarkable number of studies, an infectious etiology in the development of UC has been identified. $13,14,15$

Despite a large number of published reports, the precise involvement of $\mathrm{CMV}$ in these patients remains unknown. In 1961, the first relationship between CMV and UC was discovered. ${ }^{13}$ Infection with CMV may cause serious systemic disease and lead to colectomy in UC patients, particularly those who are immunodeficient due to steroid treatment or any form of immunodeficiency. ${ }^{14,15}$ During their follow-up of UC patients, many clinicians, however, underestimate the significance of CMV as a UC aggravating factor. PCR has proven to be the best sensitive laboratory test designed for detecting viral infections, including CMV infection. ${ }^{16}$

In the current study, CMV was detected in ulcerative colitis tissues by PCR in $6.6 \%$ of diabetic patients, with a higher prevalence among the female gender, and $2.5 \%$ of non-diabetic patients, with a higher prevalence among the male gender. This finding matched that of Meng-Tzu et al. ${ }^{17}$ who founded a higher incidence of females with CMV colitis in their study, as they assumed that is due to the higher rate of autoimmunity in females, making them more susceptible to opportunistic infections like CMV. However, Delvincourt et al. ${ }^{18}$ found a slight increase in CMV colitis in males, which could be due to the small number of females in their study.
In our study, CMV associated UC was noticed to be more common in old age patients. This finding is in line with the earlier study done by Meng-Tzu et al. ${ }^{17}$ who reported that CMV infected UC patients are older as the median age of the patients was 61.3 years. ${ }^{17}$ Although a recent case report study discovered an increased prevalence of CMV associated colitis in infants and young teenagers, which may be a latent congenital infection as they found a high proportion of male infants and young children were associated with CMV activating colitis which may be attributed to the noticed differences among host immune defenses (X-linked or otherwise) against CMV and a problem in innate immune system toll-like receptor-2 and 4 (TLR-2, 4) that regulate the host innate responses to CMV. ${ }^{19}$

As the metabolic syndrome is considered an immunocompromised condition, diabetes mellitus is considered a risk factor for increased infections associated with ulcerative colitis in the current study. In previous research and analyses, the same correlations were discovered and concluded. A case control study done on a large scale on 2049 cases found that 1200 cases with IBD, 488 with UC, and 146 cases were associated with infectious agents, including CMV. ${ }^{20}$

CMV DNA was identified in 9 of the 185 individuals in our study, 7 of them were diabetic and 2 of them were not. According to the findings, there is a correlation between CMV and UC. In the study of Maharani et al. 2015 CMV DNA was found in $80 \%$ of ulcerative colitis samples (4 of 5) and $30 \%$ of the non-malignant control group (9 of 30) with a statistically significant association between the prevalence of CMV and incidence of ulcerative colitis in comparison with the control group $(\mathrm{p}=0.03) .{ }^{9}$ Also, a strong positive association between CMV and UC was concluded by Dimitroulia et al. ${ }^{21}$ as they reported that patients with ulcerative colitis had more often detectable CMV genome in their blood as well as in their intestinal tissue samples as compared with controls $\left(\mathrm{P}=0.022\right.$ and $\mathrm{P}<0.0001$, respectively). ${ }^{22}$ The same relation between CMV and UC was noticed by Kishore et al. ${ }^{22}$ who reported that CMV infection in patients with IBD may be common $(15.8 \%$ of the studied patients) and associated with poor outcome and also, they concluded that PCR of rectal biopsy was the most sensitive method of detection of CMV infection. ${ }^{22}$

On the other hand, in the study of Leveque et al. ${ }^{23}$ the CMV genome was found in the colonic mucosa by PCR in $7(10.4 \%)$ of the 67 colonic biopsies corresponding to 7 patients $(13.2 \%)$ : $3(15 \%)$ of those with ulcerative colitis and $4(12.1 \%)$ of those with Crohn's disease. CMV infection incidence was not statistically significant between the two types of IBD and the relationship between CMV reactivation and the onset or the severity of IBD exacerbation remains debatable. ${ }^{23}$ The lack of a connection between CMV infection and UC in previous studies may be due to a small number of studied patients, immunocompetency among the groups studied, or the use of different genomic detection techniques. 


\section{CONCLUSION}

Our observations, noticed a positive connection between CMV infection and UC especially in diabetic patients. However, the pathogenesis of CMV in UC patients' needs to be studied on large groups with different risk factors.

\section{REFERENCES}

1. Lamb CA, Kennedy NA, Raine T, et al.British Society of Gastroenterology consensus guidelines on the management of inflammatory bowel disease in adults. Gut. 2019 Dec;68(Suppl 3):s1-s106. doi: 10.1136/gutjnl-2019-318484.

2. Singh S, Feuerstein JD, Binion DG, et al. AGA Technical Review on the Management of Mild-toModerate Ulcerative Colitis. Gastroenterology. 2019;156(3):769-808.e29. doi: 10.1053/j.gastro.2018.12.008.

3. Varani, S. and Landini, M.P. Cytomegalovirusinduced immunopathology and its clinical consequences. Herpesviridae 2011, 2, 6.

4. Park, S.C. Jeen, Y.M and Jeen, Y.T. Approach to cytomegalovirus infections in patients with ulcerative colitis. Korean J. Intern. Med. 2017, 32, 383-92.

5. Fakhreddine, A.Y. Frenette, C.T. and Konijeti, G.G. A Practical Review of Cytomegalovirus in Gastroenterology and Hepatology. Gastroenterol. Res. Pract. 2019, 6156581.

6. Berry, R.; Watson, G.M.; Jonjic, S.; Degli-Esposti, M.A.; Rossjohn, J. Modulation of innate and adaptive. Immunity by cytomegaloviruses. Nat. Rev. Immunol. 2020, 20, 113-127.

7. Picarda, G. and Benedict, C.A. Cytomegalovirus: Shape-Shifting the Immune System. J. Immunol. 2018, 200,3881-9.

8. Mehrabani-Khasraghi S, Ameli M, Khalily F, et al. Zahedan.Prevalence of Cytomegalovirus Infection in Patients with Ulcerative Colitis by Using PCR Technique. J Res Med Sci. 2015 ; 17(11):e2218. doi: 10.17795/zjrms-2218.

9. Carey RB, Bhattacharyya S, Kehl SC, et al. Practical Guidance for Clinical Microbiology Laboratories: Implementing a Quality Management System in the Medical Microbiology Laboratory. Clin Microbiol Rev. 2018;31(3):e00062-17. doi:10.1128/CMR.00062-17

10. Mohammed Vashist N, Samaan M, Mosli MH, et al. Endoscopic scoring indices for evaluation of disease activity in ulcerative colitis. Cochrane Database of Systematic Reviews 2018, Issue 1. Art. No.: CD011450. DOI: 10.1002/14651858.CD011450.

11. IBM Corp. Released 2019. IBM SPSS Statistics for Windows, Version 26.0. Armonk, NY: IBM Corp.

12. Campieri M and Gionchetti P. Bacteria as the cause of ulcerative colitis. Gut. 2001; 48(1):132-5.
13. Powell RD, Warner NE, Levine RS, et al. Cytomegalic inclu- sion disease and ulcerative colitis. 1961; (2):334-40. doi: 10.1016/00029343(61)90105-x.

14. Kushkevych I, Martínková K, Vítězová M, et al. Intestinal Microbiota and Perspectives of the Use of Meta-Analysis for Comparison of Ulcerative Colitis Studies. J Clin Med. 2021 26;10(3):462. doi: 10.3390/jcm10030462.

15. Yi F, Zhao J, Luckheeram RV, et al. The prevalence and risk factors of cytomegalovirus infection in inflammatory bowel disease in Wuhan, Central China. Virol J. 2013 1;10:43. doi: 10.1186/1743422X-10-43.

16. Henmi $\mathrm{Y}$, Kakimoto $\mathrm{K}$, Inoue $\mathrm{T}$, et al. Cytomegalovirus infection in ulcerative colitis assessed by quantitative polymerase chain reaction: risk factors and effects of immunosuppressants. $J$ Clin Biochem Nutr. 2018;63(3):246-51. doi: 10.3164/jcbn.18-14.

17. Weng MT, Tung CC, Lee YS, et al. Cytomegalovirus colitis in hospitalized inflammatory bowel disease patients in Taiwan: a referral center study. $B M C$ Gastroenterol. $2017 \quad$ 13;17(1):28. doi: 10.1186/s12876-017-0586-9.

18. Delvincourt M, Lopez A, Pillet S, et al. The impact of cytomegalovirus reactivation and its treatment on the course of inflammatory bowel disease. Aliment Pharmacol Ther. 2014;39(7):712-20. doi: 10.1111/apt.12650.

19. Paul K. Sue, Nicole M. Salazar-Austin, et al. Cytomegalovirus Enterocolitis in Immunocompetent Young Children: A Report of Two Cases and Review of the Literature Pediatr Infect Dis J. Pediatr Infect Dis J. 2016; 35(5): 573-6. doi: 10.1097/INF.0000000000001080.

20. Maconi G, Furfaro F, Sciurti R, et al.Glucose intolerance and diabetes mellitus in ulcerative colitis: pathogenetic and therapeutic implications. World $J$ Gastroenterol. 2014 7; 20(13):3507-15.

21. Dimitroulia E, Spanakis N, Konstantinidou AE, et al. Frequent detection of cytomegalovirus in the intestine of patients with inflammatory bowel disease. Inflamm Bowel Dis. 2006;12(9):879-84. doi: 10.1097/01.mib.0000231576.11678.57.

22. Kishore J, Ghoshal U, Ghoshal UC, et al. Infection with cytomegalovirus in patients with inflammatory bowel disease: prevalence, clinical significance and outcome. J Med Microbiol. 2004;53(Pt 11):1155-60 doi: 10.1099/jmm.0.45629-0.

23. Leveque N, Brixi-Benmansour H, Reig T, et al. Low frequency of cytomegalovirus infection during exacerbations of inflammatory bowel diseases. J Med Virol. 2010;82(10):1694-700. doi: 10.1002/jmv.21877. 